膵管癌切除症例における術中放射線照射療法の有用性

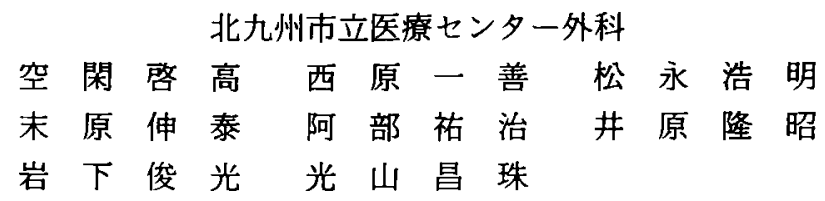

目的：脺癌は切除術を施行しても治療成績はいまだに悪く有効な補助療法の併用が不 可欠だと考えられている．そこで今回，膵癌切除後の補助療法として術中放射線照射療 法の有効性について検討した。方法：1991年 1 月から2003年12月までの13年間に当院で 行った膵管癌切除症例69例を術中放射線照射 (以下 IORT) 施行群38例と非施行群31例に 分けて各群における局所再発率と生存率を検討した。さらに臨床・病理学的因子ごとに 両群間の生存率を比較し, IORTがどのような症例に対して有用かについて検討を行っ た. 結果：IORT 施行群では非施行群と比へて有意に局所再発が低く(IORT 群7.8 ${ }^{\circ}{ }^{\circ}$, 非施行群 $\left.22.6^{\circ}{ }_{0}, \mathrm{p}<0.05\right)$, 生存率の改善も認め大 ( 5 年生存率: IORT 施行群 $29.9^{\circ}$ o, 非施行群 $\left.3.4^{\circ} \mathrm{o}, \mathrm{p}<0.05\right)$. また各因子ごとの生存率の比較では脺体尾部癌, 局所癌遺残 が R0, 局所進展度が $\mathrm{t} 1$ ，2，膵内神経叢浸閏が ne0，1の 4 因子で IORT 施行群の 5 年生 存率が有意に良好であった。一方, 性別, 膵頭部癌, 組織型, R1以上, リンパ節転移の 有無, ne2-3, 臨床病期の各因子については2 群間で生存率の有意な差はみられなかつ た. 結論：IORTは膵内に限局している膵癌を局所遺残なく切除しえた際の補助療法と して有効であり，このような症例に対しては膵癌の局所再発制御を介して生存率を改善 しうる可能性が示唆された。

索引用語：膵癌, 術中照射療法, 局所再発, 予後因子

\section{緒言}

脺癌はほとんどが診断された時点で進行癌であり, 切除例の 5 年生存率が10 20\%と極めて難治性の癌で ある ${ }^{1)-31}$. 予後不良の原因としては早期診断が困難で あり発見時にはすでに進行癌がほとんどであること， 切除可能であっても術後高頻度に局所再発や肝転移, 腹膜播種をきたすこと等が挙げられる。このうち術後 に局所再発を高率にきたす 1 つの理由として, 脺の解 剖学的な特性が考えられる。膵は後腹膜缄器であるた め, 脺癌は手術時すでに周囲組織への浸潤をきたして いる症例が多い。また, 背側には門脈, 上腸間膜動脈 などの血管が接しているために睡湯から十分なマージ ンをとって切除することが困難であり, 肉眼的には癌

2006年 1月25日受付 2006年 7 月19日採用

〈所属施設住所〉

干802-0077 北九州市小倉北区馬借 2-1-1
の遺残なく切除しえたと考えても病理組織学的な癌遺 残が多くなる゙!.

そこで，このような癌遺残による局所再発を防止す る目的で, 術中放射線照射㞠法(intraoperative radiotherapy：以下, IORT と略記)が行われるようになっ た。しかしながらその有用性については末だ明確な 結論が出ておらず，さらなる検討および報告が待たれ ている，そこで今回自験例をもとに，膵癌切除症例に 対するIORT の有用性について検討を行った。

対象および方法

1991年 1 月から2003年12月までの13年間に行った膵 癌切除症例69例を対象とした。69症例は全て通常型脺 管癌であり, Intraductal Papillary Mucinous Neoplasm 抢よび Mucinous Cystic Neoplasmは除外し た. 当院ではIORTを1997年より開始し，以後脺癌切 除症例のほほ全例に照射を行った. 今回の検討では 1996年12月までの IORT 非施行例（31例）と1997年 1 
表 1 IORT 施行症例と非施行症例の内訳

\begin{tabular}{|c|c|c|c|c|}
\hline & & $\begin{array}{c}\text { IORT 施行群 } \\
\text { (38例) }\end{array}$ & $\begin{array}{c}\text { IORT 非施行群 } \\
\text { (31例) }\end{array}$ & $\mathrm{P}$ 値 \\
\hline 性別 (男性/女性) & & $27 / 11$ & $22 / 9$ & 0.99 \\
\hline 年龄 & & $67.4(42-79)$ & $65.0(50-80)$ & 0.50 \\
\hline \multirow[t]{2}{*}{ 腫煌の部位 } & 勝頭部 & 19例 & 19例 & 0.35 \\
\hline & 体尾部 & 19例 & 12例 & \\
\hline \multirow[t]{3}{*}{ 術式 } & $\mathrm{PD}$ & 18 & 19 & 0.38 \\
\hline & DP & 19 & 12 & \\
\hline & TP & 1 & 0 & \\
\hline 腫㾺の最大径 $(\mathrm{cm})$ & & $3.7(1.0-6.2)$ & $4.3(1.9-11.7)$ & 0.39 \\
\hline \multirow[t]{4}{*}{ 組織型 } & 高分化腺癌 & 18 & 12 & 0.12 \\
\hline & 中分化腺癌 & 17 & 14 & \\
\hline & 低分化腺癌 & 3 & 1 & \\
\hline & その他・ & 0 & 4 & \\
\hline \multirow[t]{3}{*}{ 寀遭存 $(R)$} & R 0 & 23 & 17 & 0.82 \\
\hline & R 1 & 12 & 12 & \\
\hline & $\mathrm{R} 2$ & 3 & 2 & \\
\hline \multirow[t]{4}{*}{ 局所進展 (t) } & $t 1$ & 2 & 1 & 0.94 \\
\hline & $\mathrm{t} 2$ & 5 & 3 & \\
\hline & t 3 & 20 & 17 & \\
\hline & $t 4$ & 11 & 10 & \\
\hline \multirow[t]{4}{*}{ リンパ節転移(n) } & n 0 & 13 & 8 & 0.10 \\
\hline & n 1 & 15 & 10 & \\
\hline & n' & 7 & 7 & \\
\hline & n 3 & 3 & 6 & \\
\hline \multirow[t]{4}{*}{ 神経浸润(ne) } & ne 0 & 2 & 5 & 0.17 \\
\hline & ne 1 & 13 & 11 & \\
\hline & ne 2 & 18 & $x$ & \\
\hline & ne 3 & 5 & 7 & \\
\hline \multirow[t]{6}{*}{ 盬床病期 } & stage 0 & 0 & 0 & 0.70 \\
\hline & stage I & 1 & 1 & \\
\hline & stage II & 5 & 4 & \\
\hline & stage III & 16 & 8 & \\
\hline & stage IVa & 9 & 10 & \\
\hline & stage IN b & 7 & 8 & \\
\hline
\end{tabular}

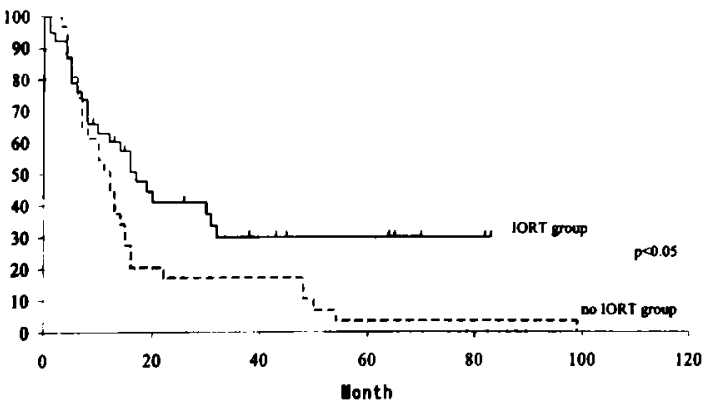

图 1IORT 施行群, 非施行群の果程生存率: 3 年, 5 年 生存率ともにIORT 施行群で有意に良好であった。
月以降のIORT 施行例（38例）における生存率をそれ ぞれ算出しIORT の有効性について retrospective に 検討した．さらに，どのような症例に対し IORT が有 効か検討するため, 以下の因子について両群間の生存 率を比較検討した，検討した因子：性別，腫瘍の占拠 部位, 組織型, 局所癌遺残 (R), 局所進展度 $(\mathrm{t}), \mathrm{J}$ ンパ節転移 $(\mathrm{n})$, 膵内神経浸潤 $(\mathrm{ne})$, 臨床病期.

IORT は膵癌切除後に上腸間膜動脈根部を中心とし た後腹膜剝離面に対して径 $6 \mathrm{~cm}$ の照射用コーンを用 いて照射線量 20 ：31) j，照射電圧20-35MeV の照射を 行った。さらに 6 例に対しては術後放射線照射を追加 
表 2 IORT 施行症例と非施行症例における再発形式

\begin{tabular}{lclclr}
\hline & IORT 施行群 (38例) & IORT 非施行群 (31例) & P 值 \\
\hline 肝転移 & 10 例 & $(26.3 \%)$ & 6 例 & $(19.4 \%)$ & 0.50 \\
腹膜播種 & 10 & $(26.3)$ & 8 & $(25.8)$ & 0.96 \\
局所再発 & 3 & $(7.8)$ & 7 & $(22.6)$ & $<0.05$ \\
リンパ節転移 & 3 & $(7.8)$ & 3 & $(9.7)$ & 0.79 \\
肺転移 & 2 & $(5.3)$ & 0 & $(0)$ & 0.20 \\
骨転移 & 0 & $(0)$ & 1 & $(3.2)$ & 0.27 \\
\hline
\end{tabular}

局所再発のみ IORT 施行群で有意に少なかった。

表 3 IORT 施行群と非施行群における各因子ごとの平均生存期間と 5 年 生存率

\begin{tabular}{|c|c|c|c|c|}
\hline 因子 & & 施行群(MST $5 \mathrm{YSR}$ ) & 非施行群 (MST/5YSR) & $\mathrm{P}$ 値 \\
\hline \multicolumn{5}{|l|}{ 性別 } \\
\hline & 男性 & 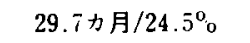 & $15.5 / 4.9$ & 0.07 \\
\hline & 女性 & $35.7 / 41.6$ & $25.4 / 0$ & 0.43 \\
\hline \multicolumn{5}{|c|}{ 占拠部位 } \\
\hline & 膵頭部 & $26.5 / 21.2$ & $18.9 / 0$ & 0.69 \\
\hline & 脺体尾部 & $42.7 / 411.6$ & $17.7 / 8.3$ & 0.02 \\
\hline \multicolumn{5}{|c|}{ 組織型 } \\
\hline & 高分化腺癌 & $41.6 / 40.4$ & $26.9 / 9.3$ & 0.36 \\
\hline & 中低分化腺癌 & $26.3 / 19.3$ & $13.3 / 0$ & 0.18 \\
\hline \multicolumn{5}{|c|}{ 局所程遗残 } \\
\hline & R 0 & $42.9 / 41.3$ & $39.3 / 5.8$ & 0.04 \\
\hline & R 1 以上 & $15.3 /-$ & $10.4 / 0$ & 0.60 \\
\hline \multicolumn{5}{|c|}{ 局所進展度 } \\
\hline & $t 1,2$ & $72.8 / 80.0$ & $44.0 / 25.0$ & 0.04 \\
\hline & t 3,4 & $25.4 / 19.4$ & $14.4 / 0$ & 0.27 \\
\hline \multicolumn{5}{|c|}{ リンパ節転移 } \\
\hline & n 0 & 50.150 .8 & $36.0 / 12.5$ & 0.26 \\
\hline & n 1 以上 & $20.6 / 15.6$ & $11.9 / 0$ & 0.11 \\
\hline \multicolumn{5}{|c|}{ 䏽内神経浸潤 } \\
\hline & ne 0,1 & $50.6 / 51.9$ & $26.6 / 6.9$ & 0.05 \\
\hline & ne 2,3 & $20.9 / 17.2$ & $10.4 / 0$ & 0.12 \\
\hline \multicolumn{5}{|c|}{ 臨床病期 } \\
\hline & stage I & $71.7 / 100$ & $99.0 / 100$ & 0.99 \\
\hline & stage II & $70.3 / 75.0$ & $31.8 / 0$ & 0.08 \\
\hline & stage IIl & $24.9 / 23.8$ & $18.3 / 0$ & 0.36 \\
\hline & stage $\mathrm{Na}$ & $27.2 / 15.6$ & $11.5 / 0$ & 0.06 \\
\hline & stage IVb & $11.4-$ & $8.9 / 0$ & 0.99 \\
\hline
\end{tabular}

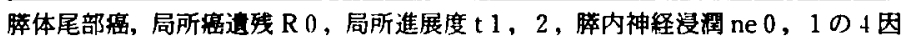
子で IORT 施行群の 5 年生存率が有意に良好であった（MST：mean survival time, 5 YSR : 5 year survival rate).

した。

術後の補助化学療法はIORT 非施行群ではテガフ 一ル・ウラシルの内服を 9 例に行った。一方, IORT 施 行群では 7 例でテガフール・ウラシルの内服, 2 例で 5-FU, CDDP の全身投与を行った. また, 術後の再発 確認は腹部超音波検査, 胸腹部 CT・MRI 検査などの
画像診断によって行った.

本研究における臨床病理学的因子の分類は本邦の脺 癌取扱い規約(第 5 版)に従い, 統計学的検討は $t$-test またはFisher's exact test を用いて行い, p<0.05を有 意差ありとした。また生存率は Kaplan-Meier 法によ り算出し Log-rank 検定を行った. 


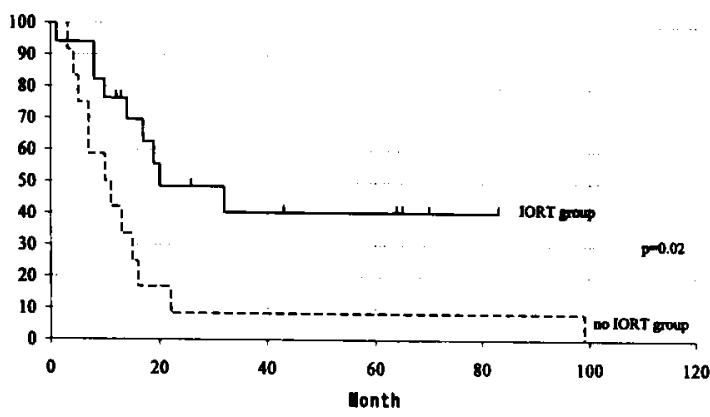

図 2 膵体尾部癌における両群の果程生存率

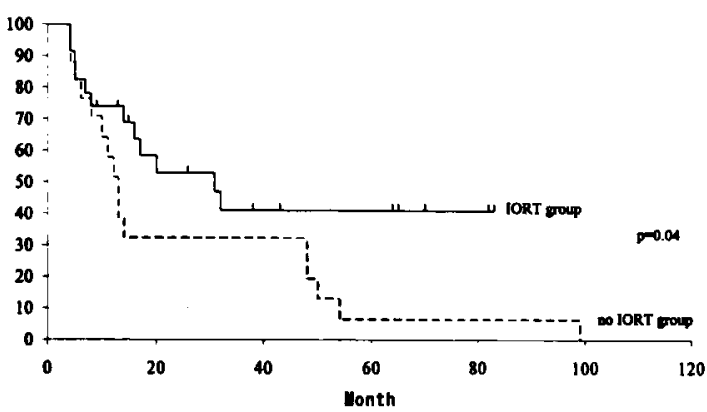

図 $3 \mathbf{R 0}$ 症例における両群の果皘生存率

\section{結果}

1. IORT 施行例と IORT 非施行例における生存率の 比較 IORT 施行群 $(n=38)$ 照射線量の内訳は30Gy： 27例, 25Gy：9 例, 20Gy：2 例であった. 6 例では20 -40Gy の後照射を追加した. IORT 非施行例 $(n=31)$ では術前・術後照射も施行していなかった. IORT 施行 症例と IORT 非施行症例の患者背景および病理学的 因子の内訳は表 1 に示す通りであり各因子で両群間に 有意な差はなかった. IORT 施行例, IORT 非施行例の 累樌生存率を図 1 に示すが，その 3 年, 5 年生存率は それぞれ IORT 施行群 $29.9 \%$ ，29.9\%，IORT 非施行 群17.0\%, 3.4\%であり, IORT 施行群で有意に予後良 好であった（p<0.05）.

全症例中 5 年生存率は 6 例 (IORT 施行群 5 例, IORT 非施行群 1 例)であった. IORT 施行群における 5 年生存 5 症例の内訳は stage I：1 例, stage II： 3 例, stage IV a：1 例であり, IORT 非施行群の 5 年 生存例 1 例は stage I であった。これらの 6 症例全例 が局所瘦遺残度 R0であった.また両群で術後再発形 式を検討すると（表 2)，IORT 施行群では肝再発10例 $(26.3 \%)$, 腹膜再発10例 (26.3\%), 局所再発 3 例 $(7.8$

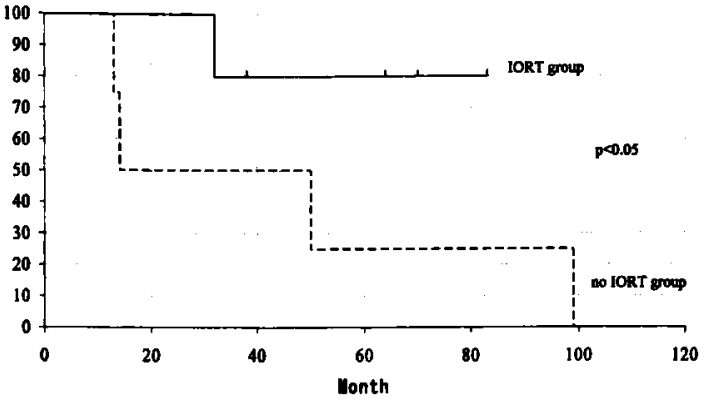

图 4 t1，2症例における両群の果积生存率

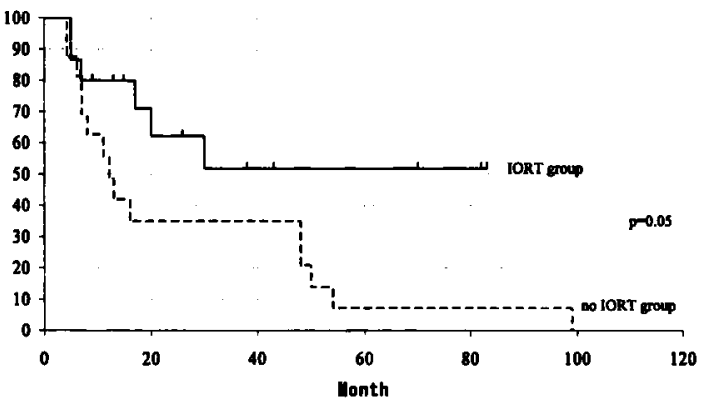

図 5 ne0，1 症例における両群の果䅡生存率

$\%)$, リン八゚節再発 3 例 (7.8\%), 肺·胸膜再発 2 例 (5.3 \%)であり，IORT 非施行群では肝再発 6 例 (19.4\%), 腹膜再発 8 例 $(25.8 \%)$, 局所再発 7 例 $(22.6 \%)$, リ ンパ節再発 3 例 $(9.7 \%)$ ，骨再発 1 例 (3.2\%) でっ た. 再発形式では局所再発のみが IORT 施行群で有意 に少なかった（p<0.05）.

\section{2. 各因子ごとの両群間の生存率比較}

IORT 施行群と非施行群の間で有意に生存率を改善 する臨床病理学的因子につき検討するため, 以下の各 因子ごとに両群間で生存率の比較を行った. 検討した 因子は性別（男性・女性）, 睡場の占拠部位（膵頭部・ 脺体尾部), 組織型 (高分化腺癌-中低分化腺癌), 局 所癌遣残（R）（R0・R1以上，局所進展度（t）（t1， $2 \cdot \mathrm{t} 3,4)$ ，リン八゚節転移 (n) (n0・n1以上), 勝内神 経浸潤（ne）（ne0，1・ne2，3）, 臨床病期（stage I• II ・ III ・ IV a・IV b). 各因子に抢ける両群の平均生存 期間と 5 年生存率を表 3 に示す. 検討した因子のうち IORT 非施行群と比へIORT 施行群で有意に予後良

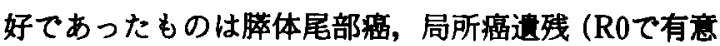
に予後良好)，局所進展度 $(\mathrm{t} 1 ， 2)$, 膵内神経漫润 (ne0, 1)であった（有意差のみられた各因子における累積生 
存率のグラフを図 $2 \sim 5$ に示す). 性別, 膵頭部癌, 組 織型, R1以上, リンパ節転移の有無, ne2-3, 臨床病期 の各因子ではIORT 施行群と非施行群との間で有意 な生存率の改善はみられなかった。

\section{考察}

脺癌の集学的治療の 1 つとして切除症例に対して IORTが行われるようになった. IORT は体外照射に 比へて実際に目で確かめながら癌遺残の可能性がある 部分を照射範囲として決定でき，腸管等の臓器をよけ て照射することで副作用を軽減し照射の必要な部分に のみ高線量を照射できるといったメリットがある゙．

膵癌切除症例に対するIORT の効果についてはま だ明らかになっていない，膵癌喰療ガイドラインでも 膵癌の術中放射線療法の推奖についてはグレードC であり,"行うよう勧めるだけの根拠が明確でない”と されている6. これまでの IORT の効果に関する報告 ごは, 局所再発のコントロールに関して IORT は有効 であるとする複数の報告がされているが，生存期間に 及はす影響については結果が一定していないて23).中 尾によると膵癌切除143例中67例にIORT を施行した 結果, 傽癌取扱い規約第 3 版による stage III症例では IORT 施行群で有意に予後良好であったと報告してい る゙.この他にもIORTにより生存率が有意に改善し たとする報告がいくつかある(1012) 14. Hosotani らは 膵癌150切除症例の86例に対して補助放射線療法 (IORT および術後照射)を行い, 補助放射線療法群で は手術単独群と比へて Median Survival Time が有意 江延長し(手術単独群7.9力月, 補助放射線療法群 12.8 力月), 特に T3症例, リンパ節転移陽性症例, 局所癌 遺残のない 0 症例に対して有効であったと報告して いる ${ }^{12)}$. 岡本らの検討でも全症例では生存率に有意差 はみられなかったもののリンパ節転移を有する TNM stage III症例ではIORT 群で有意に生存率が良好であ ったとしている(10). 一方で Sunamura らは膵癌60症例 に対して切除ひみ!例，切除+IORT33例について生 存率を比較しているが有意差はみられていない吾。こ の他にも有意な予後改善効果はみられなかったとする 報告も多数みられる ${ }^{1115) ~ 231 . ~}$

今回の検討では IORT 施行群では非施行群に比へ て局所再発の制御のみならず生存率も有意に良好であ つた。变癌の再発形式については諸家の報告があるが, 主な再発部位として肝, 局所, 腹膜が挙げられてい

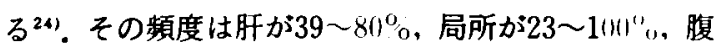
膜が17〜 56\%と報告されている24) 28).これらの再発形
式のうち IORT の効果があるのは局所再発の制御と 考えられるが, 今回の検討結果でもIORT は局所再発 を有意に抑制していた。一方, 両群間で肝再発や腹膜 再発の頻度には有意な差はみられなかった. IORT の 局所再発抑制についての報告はエビデンスレベルIVで はあるが，効果があるとする複数の報告があり，遠隔 転移がなく局所再発のみをきたすような症例に対して は予後を改善する可能性が十分に考えられる(14)-17.

今回の結果に関しては retrospective な検討であり 両群の治療を行った時期も異なっていることを念頭に 置く必要がある. 一方で, この十数年間における膵癌 の治療成績を考えると大きな変化はなく, 今回の比較 検討ではIORT 施行群で明らかに予後良好であった。 IORT の効果について切除単独と比較したランダム化 比較試験の結果がでていない現時点では, 今回の検討 は許容されるのではないかと思われた。

各因子ごとの両群間の予後解析では膵体尾部癌, 局 所癌遺残 $(\mathrm{R} 0)$ ，局所進展度 $(\mathrm{t} 1,2)$, 膵内神経浸潤 (ne0, 1）の 4 因子で IORT 施行群の生存率が有意に良好で あった.この4つの因子のうち, 局所癌遺残について は, R0症例での 5 年生存率が IORT 施行群で $41.3^{\circ}$ o, IORT 非施行群で5.8”でありR1以上の症例では IORT を施行しても5年生存例はなかった。また， t3， 4やne?, 症例でも IORT による予後の改善はみられ ておらず,局所進展の強いものや癌遺残を認める R1以 上の症例ではIORTを併用しても予後の改善は認め られないと考えられた。これは R0症例に对してIORT は有効な補助療法の 1 つとする Hosotani らの報告 ${ }^{12}$ と同様の結果であった. Hosotani らは理論的には R1 症例に対して IORT が有効と思われるがR1症例では 有意な survival advantageはみられなかったと述べ ている ${ }^{12)}$. 今回のデータを基に RII症例のみを比較して みても有意差はみられ寸゙ $(\mathrm{p}=0.55)$, IORT は R0症例 に対して有用性があると考えられた。

臨床病期ごとの検討では,どの病期においても IORT の有意な生存率改善はみられなかった。病期と IORTに関する報告例は脺癌取扱い規約第 3 版の stage IIIおよびTNMI 分類の第 2 版における stage III でIORT が有効であったとするものがあるか10)。これ らの stage IIIは分類法が全く異なっており, 今回の検 討も膵癌取扱い規約第 5 版に基づいているため単純な 比較はできないと考えられた。一方，Reniらは膵癌治 疮切除例203症例に対する IORT の検討で stage I, IIではIORTが予後を有意に改善したと報告してお 
$\eta^{14)}$ どの病期に対してIORT が有効なのについても

一定の見解が得られていないのが現状である.

今回の検討の結果, IORT は膡癌切除全症例に対し

て有効性がある訳ではなく，外科的に遺残なく切除さ れた膵癌症例に対する局所補助療法として有用である 可能性が示唆された。このような症例ては IORT が局 所再発を抑制し，その結果として生存率を改善する可 能性が示された。脺癌切除症例に対する IORT の併用 については末だにエビデンスレベルの高い報告はな く，今後 IORT の効果について十分な症例を対象とし た詳細な検討が必要だと思われた。現在本邦で randomized clinical trial が進行中であり，その結果が待 たれる.

\section{結 語}

IORT は外科的に遺残なく切除された缕癌症例に対 する局所補助療法として有用であると考えられた。そ のような症例ては IORT が局所再発を抑制し，その結 果として生存率を改善する可能性が示された。

\section{文献}

1）がんの統計編集委員会：がんの統計 '01. 盰団法 人がん研究振興財団, 東京, 2001，p42-43

2）江川新一, 砂村真琴, 島村弘宗他：術後迋隔成績 からみた進行膵癌の治療成績. 消外 $21 ： 1081-$ 1090,1998

3）江川新一，松野正紀：日本膡䑏学会膀癌登録20年 間の統括. 膵䑏 $18: 101-169,2003$

4）乙供茂，砏村員琴，元井冬彦他：5-FU 併用 chemoradiation と Gemcitabine で根治手術が可 能となった局所進行俨頭部癌の 1 例. 日消外会誌 $37: 434-439,2004$

5）西村恭昌，小久保雅樹，金森修一他：術中照射法 による勝がんの治畨. Innervision $12: 43-47$, 1997

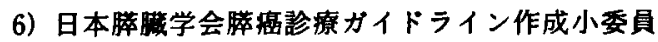
会：膵票猃療ガイドライン.金原出版, 東京, 2006, $\mathrm{p} 82-83$

7) 中尾昭公：滕䍃に対する術中照射療法 (IORT). 医のあゆみ $176: 693-695,1996$

8) Sunamura M, Kobarai $M$, Lozonschi $L$, et al : Intraoperative radiotherapy for pancreatic adenocarcinoma. J Hep Bil Pancr Surg 5 : 151 $-156,1998$

9) Alfieri S, Morganti AG, Di Giorgio A, et al: Improved survival and local control after intraoperative radiation therapy and postoperative radiotherapy : a multivariate analysis of 46 patients undergoing surgery for pancreatic head cancer. Arch Surg $136: 343-347,2001$

10）岡本第武, 鶴田耕二, 江川直人他：治疼切除され た膵頭部癌に対する術中照射療法の成續. 脺臟 $12: 407-413,1997$

11) Nishimura $Y$, Hosotani $R$, Shibamoto $Y$, et al : External and intraoperative radiotherapy for resectable and unresectable pancreatic cancer: analysis of survival rates and complications. Int J Radiation Oncology Biol Phys 39 : 39-49, 1997

12) Hosotani R, Kogire M, Arii $S$, et al : Results of pancreatectomy with radiation therapy for pancreatic cancer. Hepato-Gastroenterology 44 : 1528-1535, 1997

13）平岡武久, 金光敬一郎, 过 龍也：膵癌切除例に 对する術中放射線療法の評価.日外会誌 $98: 628$ $-632,1997$

14) Reni M, Panucci MG, Ferreri AJ, et al : Effect on local control and survival of electron beam intraoperative irradiation for resectable pancreatic adenocarcinoma. Int $\mathrm{J}$ Radiat Oncol Biol Phys 50 : 651-658, 2001

15) Zebri A, Fossati V, Parolini D, et al : Intraoperative radiation therapy adjuvant to resection in the treatment of pancreatic cancer. Cancer 73 : 2930-2935, 1994

16) Fossati V, Cattaneo GM, Zebri A, et al: The role of intraoperative therapy by electron beam and combination of adjuvant chemotherapy and external radiotherapy in carcinoma of the pancreas. Tumori $81: 23-31,1995$

17）藤川貴久，松末 智，長谷川傑他：勝䠛に対する 術中放射線療法(IORT). 天理医紀 $2: 20-31$ ， 1999

18）中迫利明, 羽生富士夫, 今泉俊秀他：梳頭部癌切 除例に対する術中照射療法の検討，日臨外医会誌 $53: 549-556,1992$

19) Ross HM, Kurtzman SH, Macauly WP, et al: Resection for cure of adenocarcinoma of the head of the pancreas: the greater Hartford experience. Conn Med 61:3-7, 1997 
20) Di Carlo V, Zerbi A, Balzano G, et al : Intraoperative and postoperative radiotherapy in pancreatic cancer. Int $\mathbf{J}$ Pancreatol 21 : 5358. 1997

21) Dobelbower RR, Merrick HW, Khuder S, et al : Adjuvant radiation therapy for pancreatic cancer : a 15-year experience. Int J Radiat Oncol Biol Phys $39: 31-37,1997$

22）阿部哲夫，伊藤 契，阿川千一郎他：膵癌に対す る術中照射療法の成續と合併症. 日消外会誌 $34: 459-464,2001$

23）砂田祥司，小関萬里，中場寛行他：膵癌切除症例 に対する術中照射療法の検討. 広島医 $54: 520-$ 522,2001

24）濱崎啓介：脺癌の再発診療に関する最新のデー 夕. 臨外 $57: 263-269,2002$

25) Kayahara M, Nagakawa T, Ueno $K$, et al : An evaluation of radical resection for pancreatic cancer based on the mode of recurrence as determined by autopsy and diagnostic imaging. Cancer $72: 2118-2123,1933$

26) Takahashi S, Ogata $Y$. Miyazaki H, et al: Aggressive surgery for pancreatic duct cell cancer : feasibility, validity, limitations. World J Surg 19:653-660, 1955

27) Nakao $A$, Inoue $S$, Nomoto $S$, et al : Extended radical surgery for pancreatic carcinoma : indications and oncological problems. Asian J Surg $20: 192-197,1997$

28）土井隆一郎, 藤木康二, 今村正之：脺癌外科治療 の問題点と今後の展望. 外科 $63: 1720-1727$, 2001

\title{
INTRAOPERATIVE RADIOTHERAPY COMBINED WITH RESECTION FOR PANCREATIC CANCER-ANALYSIS OF SURVIVAL RATES AND PROGNOSTIC FACTORS-
}

\author{
Hirotaka KUGA, Kazuyoshi NISHIHARA, Hiroaki MATSUNAGA, Nobuhiro SUEHARA, \\ Yuji ABE, Takaaki IHARA. Toshimitsu IWASHITA and Shoshu MIITSLIAMA \\ Department of Surgery, Kitakyushu Municipal Medical Center
}

Purpose : The purpose of this study was to evaluate the efficiency of intraoperative radiotherapy (IORT) combined with surgical resection.

Methods : Subjects were consecutive 69 patients with pancreatic cancer treated with surgery alone $(\mathrm{n}=$ 31 ) or surgical resection combined with IORT $(n=38)$ in a 13 year period between 1991 and 2003 . We evaluated the effects of IORT against local recurrence of cancer and patients' survival, retrospectively. Furthermore, clinicopathological factors affecting the 5-year survival rate in the two groups were comparatively investigated.

Results : The IORT group showed a significantly lower local recurrence rate of cancer than that in the surgery alone group $(7.8 \%$ and $22.6 \%$, respectively $; \mathrm{p}<0.05)$. The 5 -year survival probability in the IORT group was significantly higher than that in the surgery alone group $(29.9 \%$ and $3.4 \%$, respective$1 y ; p<0.05)$. According to the Japanese classification of pancreatic cancer, cancers located in the pancreas body or tail, no local residual cancer post operative procedure (R0), low grade local cancer progression ( $t 1,2)$, and low grade intrapancreatic neural invasion (ne0, 1) were significantly better prognostic factors in the IORT group than those in the surgery alone group. There were no significant differences between the both groups in the 5-year survival rate in terms of the sex of the patients. cancer of the pancreas head, histological type, more than R1, the presence of lymph node involvement, ne'- -3 , and clinical stages.

Conclusion: IORT is a useful intraoperative adjuvant therapy for pancreatic cancer, when the curative resection is achieved. Our data have suggested that IORT suppresses the local recurrence of cancer and provides the significant survival benefit for those patients. 